\title{
Poor insight into memory impairment in patients with Huntington disease
}

\section{Ograniczony wglq̨d w zaburzenia pamięci u osób z chorobq Huntingtona}

\author{
Emilia J. Sitek ${ }^{1,2}$, Witold Sottan', Piotr Robowski ${ }^{1,2}$, Michał Schinwelski ${ }^{1,2}$, Dariusz Wieczorek ${ }^{3}$, Jarosław Stawek ${ }^{1,2}$ \\ 1Oddział Neurologii, Szpital Specjalistyczny św. Wojciecha w Gdańsku \\ 2Zakład Pielęgniarstwa Neurologiczno-Psychiatrycznego, Gdański Uniwersytet Medyczny \\ ${ }^{3}$ Katedra i Klinika Rehabilitacii, Gdański Uniwersytet Medyczny
}

Neurologia i Neurochirurgia Polska 2012; 46, 4: 318-325

DOI: 10.5114/ninp.2012.30262

\begin{abstract}
Background and purpose: Patients suffering from Huntington disease (HD) have been shown to present with poor selfawareness of a variety of symptoms. The study aimed to assess the self-awareness of memory impairment in HD in comparison to advanced Parkinson disease (PD), mild PD and cervical dystonia.
\end{abstract}

Material and methods: Self-awareness was tested in 23 patients with HD by comparing patient and caregiver ratings in reference to clinical control groups (25 patients with advanced PD, 21 with mild PD and 20 with cervical dystonia). Self-awareness was tested using the Self Rating Scale of Memory Functions, which was administered to both the patients and the caregivers. Neuropsychological assessment addressed general cognitive status (Mini-Mental State Examination), verbal learning (Auditory Verbal Learning Test, 15-word list) and mood (Montgomery-Asberg Depression Rating Scale).

Results: Patients with HD significantly underestimated their memory dysfunction. Underestimation of memory deficit correlated with disease duration and disease severity in $\mathrm{HD}$.

Conclusions: Huntington disease patients underestimate memory dysfunction. These results add to the previous reports on poor insight in HD in other domains and suggest that anosognosia in HD, albeit usually rather mild, may be a generalized phenomenon.

Key words: Huntington disease, verbal learning, awareness.

\section{Streszczenie}

Wstęp i cel pracy: U pacjentów z chorobą Huntingtona $(\mathrm{ChH})$ stwierdza się zaburzoną samoświadomość wielu objawów. Badanie miało na celu ocenę samoświadomości zaburzeń pamięci u chorych na $\mathrm{ChH}$ w porównaniu z chorymi na zaawansowaną chorobę Parkinsona (ChP), ChP z niewielkim nasileniem objawów oraz chorymi na dystonię szyjną. Materiał i metody: Samoświadomość zaburzeń pamięci zbadano u 23 chorych na ChH poprzez porównanie ocen pacjentów i opiekunów w odniesieniu do klinicznych grup porównawczych (25 chorych na zaawansowaną ChP, 21 chorych na ChP z niewielkim nasileniem objawów oraz 20 chorych na dystonię szyjną). Samoświadomość zaburzeń pamięci zbadano przy użyciu skali Samooceny funkcjonowania pamięci (Self Rating Scale of Memory Functions), którą wypełniali zarówno pacjenci, jak i opiekunowie. W badaniu neuropsychologicznym oceniano ogólny stan funkcjonowania poznawczego (Mini-Mental State Examination), uczenie się materiału słownego (Auditory Verbal Learning Test, lista 15 słów) oraz nastrój (Montgomery-Asberg Depression Rating Scale).

Wyniki: Chorzy na $\mathrm{ChH}$ nie byli w stanie właściwie ocenić nasilenia zaburzeń pamięci, uważając, że funkcjonuje ona lepiej, niż to było w rzeczywistości. Tendencja ta korelowała z czasem trwania choroby oraz nasileniem jej objawów.

Wnioski: Chorzy na ChH nie zdają sobie w pełni sprawy z nasilenia zaburzeń pamięci. Uzyskane wyniki wspierają wcześniejsze doniesienia $\mathrm{z}$ piśmiennictwa o zaburzonym wglądzie w ChH dotyczącym wielu sfer funkcjonowania i sugerują, że anozognozja w $\mathrm{ChH}$, aczkolwiek zazwyczaj raczej łagodna, może mieć charakter uogólniony.

Słowa kluczowe: choroba Huntingtona, uczenie się materiału słownego, świadomość.

Correspondence address: dr Emilia Sitek, Zakład Pielęgniarstwa Neurologiczno-Psychiatrycznego, Gdański Uniwersytet Medyczny, Al. Jana Pawła II 50, 80-462 Gdańsk, Poland, e-mail: emsitek@gmail.com

Received: 26.12.2011; accepted: 6.04.2012 


\section{Introduction}

Huntington disease (HD) is an autosomal dominant inherited neurodegenerative disorder characterized by motor, psychiatric and cognitive symptoms [1,2]. Slight cognitive impairment usually affects individuals at the preclinical stage of the disease, a few years before the onset of motor symptoms [3]. Executive deficits and working memory impairment predominate in the cognitive profile of HD. However, episodic memory and spatial function are also significantly affected $[2,4,5]$.

Memory deficits in HD concern declarative memory ("know what" - this type of memory refers to both episodic and semantic memory) $[4,6]$ and non-declarative memory ("know how", procedural memory among other things) [7-9]. Episodic memory deficits may appear relatively early, even at the preclinical stage [10]. More specifically, temporal order memory deficits are observed in asymptomatic gene carriers [11]. At more advanced disease stages, it can be observed that the retrograde amnesia in HD does not follow the temporal gradient, typical for Alzheimer disease (AD), where information from the remote past is much better recalled than recent events [12]. In $\mathrm{HD}$ it makes an interview with the patient rather difficult, as the patient usually cannot recall many facts (e.g. childhood diseases) or put them in the correct chronological order. Another specific feature of memory impairment in HD is the difficulty with recalling the spatial localization of objects. In contrast to $\mathrm{AD}$, HD patients recall the object better than its spatial localization [13].

Tasks assessing episodic memory (delayed recall measures from Wechsler Memory Scale and most scores from California Verbal Learning Test, CVLT) are particularly sensitive in detecting cognitive impairment in HD [14]. Results of verbal learning assessment in HD using the CVLT, Hopkins Verbal Learning Test (HVLT) and Rey Auditory Verbal Learning Test (RAVLT) reveal a pattern typical for subcortical dementia: low learning curve, slight problems with delayed recall, and marked improvement in cued recall or in recognition trials $[15,16]$.

HD patients may not be fully aware of the presence or severity of a variety of symptoms: (a) motor (mainly chorea) [17-19], (b) disability in the activities of daily living [20,21], (c) emotional problems [21,22], and (d) executive dysfunction [23]. Inadequate self-report of one's function may even precede the clinical diagnosis of $\mathrm{HD}$ [24]. To our knowledge, none of the previous studies have addressed self-awareness of memory impairment in HD. The present study aimed to assess insight into memory impairment in patients with HD through the comparison with patients with advanced Parkinson disease (PD), mild symptoms of $\mathrm{PD}$, and patients with cervical dystonia. The clinical comparison groups were chosen because of the common clinical characteristics in terms of mood and motor symptoms (high prevalence of depression, the presence of involuntary movements evident to a neurologically-naïve observer, possibly leading to stig$\mathrm{ma}$ ) and the differences in the cognitive status. In order to exclude the influence of general cognitive status on the patients' ratings, the advanced $\mathrm{PD}$ group was matched to the HD group according to Mini-Mental State Examination (MMSE) scores [25]. The group with mild PD was chosen as it was supposed to have less impaired memory than the HD and advanced PD groups (in terms of learning efficiency and delayed recall). Cervical dystonia was chosen as a reference group as this disease does not lead to cognitive impairment, but this patient group shares some emotional and motor problems with $\mathrm{HD}$ and $\mathrm{PD}$, as mentioned before. What is more, only this group could be matched to the HD group in terms of age, without a selection bias. The cervical dystonia group was chosen instead of a healthy control group so as to enable matching of this group to the HD group in terms of mood.

The assessment of self-awareness in neurodegenerative disorders is performed using one or more of the following types of measurement: clinician rating methods, questionnaire-based methods, performance-based methods, phenomenological methods or multidimensional/combined methods [26]. In the present study, we decided to use combined methods: patient-caregiver comparison and the comparison of subjective ratings against the objective criterion (memory test performance). Previous studies analysing self-awareness in HD used either only clinician rated methods [20], patient-caregiver comparison [23] or a performance-based method [18] in isolation or, most commonly, using a combined approach $[17,19$, $21,22]$. Only patient-caregiver comparison of the patient's memory function was performed in this study (without control assessment of patients' ratings of collaterals' function) as previous studies demonstrated clearly that the judgement deficit in HD concerns only rating one's own abilities and not others' $[21,23]$.

The study assessed the concordance of patients and caregivers in reference to the patients' memory and the concordance of both patients' and caregivers' ratings with the objective criterion of scores obtained in the memory testing. It was hypothesized that the HD patients would underestimate memory impairment, both with reference to caregivers' ratings and to objective performance. 


\section{Material and methods}

\section{Patients}

Eighty-nine patients from the Movement Disorders Clinic (St. Adalbert Hospital, Gdansk, Poland) participated in the study (23 with HD, 25 with advanced PD, 21 with mild PD and 20 with cervical dystonia). The patients were diagnosed according to the established clinical criteria for HD [1], PD [27] and cervical dystonia [28]. Other diagnoses were excluded by neuroimaging (computed tomography or magnetic resonance imaging) and laboratory testing. In HD patients, the clinical diagnosis was confirmed by genetic testing. The main inclusion criterion was MMSE score $\geq 20$, which enabled further neuropsychological and questionnaire assessment. Patients with concurrent neurological disorders, with a history of alcohol abuse, with severe (oculo)motor impairment (unable to stay in a sitting position for an hour and/or unable to read), and those who did not have a caregiver willing to participate, spending most of the time with the patient and having known him/her prior to the disease onset, were excluded from the study. The word caregiver was consequently used in the whole paper to refer to the patient's proxies, who in the case of some patients (with PD and cervical dystonia) were not caregivers, but just companions.

Demographic and clinical data are presented in Table 1. The groups were matched in terms of sex and

Table 1. Clinical and demographic data of patients with Huntington disease (HD), advanced Parkinson disease (PD), mild PD and cervical dystonia

\begin{tabular}{|c|c|c|c|c|c|}
\hline & $\begin{array}{l}\text { Patients with } \mathrm{HD} \\
\qquad N=23 \\
{[\mathrm{~A}]}\end{array}$ & $\begin{array}{c}\text { Patients with } \\
\text { advanced PD } \\
N=25 \\
{[\mathrm{~B}]}\end{array}$ & $\begin{array}{l}\text { Patients with mild PD } \\
\qquad \begin{array}{c}N=21 \\
{[\mathrm{C}]}\end{array}\end{array}$ & $\begin{array}{l}\text { Patients with } \\
\text { cervical dystonia } \\
N=20 \\
{[\mathrm{D}]}\end{array}$ & $\begin{array}{l}P \text {-value for } \\
\text { differences } \\
\text { between } \\
\text { groups }\end{array}$ \\
\hline Age [years], mean $\pm \mathrm{SD}$ & $49.83 \pm 11.12$ & $65.68 \pm 10.03$ & $64.67 \pm 7.59$ & $51.75 \pm 12.98$ & $\begin{array}{l}\quad p<0.001^{*} \\
\text { A vs. B, A vs. C, } \\
\text { B vs. } \mathrm{D}, \mathrm{C} \text { vs. } \mathrm{D}\end{array}$ \\
\hline Education [years], median & 12 & 12 & 13 & 12 & $0.57^{* * *}$ \\
\hline Sex ratio [men/women] & $14 / 9$ & $12 / 13$ & $15 / 6$ & $8 / 12$ & $0.18^{* * * *}$ \\
\hline $\begin{array}{l}\text { Disease duration [years], } \\
\text { median }\end{array}$ & 5 & 12 & 4 & 8 & $\begin{array}{l}<0.0001^{* * *} \\
\text { A vs. B, B vs. C }\end{array}$ \\
\hline $\begin{array}{l}\text { Unified Parkinson's Disease } \\
\text { Rating Scale - part III } \\
\text { score }[\text { pts], mean } \pm \text { SD }\end{array}$ & - & $22.04 \pm 9.14$ & $18.29 \pm 10.38$ & - & $0.20^{\dagger}$ \\
\hline Daily levodopa dose [mg], median & - & 1000 & 500 & - & $0.002 \ddagger$ \\
\hline $\begin{array}{l}\text { Unified Huntington's Disease } \\
\text { Rating Scale - motor score } \\
{[\text { pts], mean } \pm \mathrm{SD}}\end{array}$ & $38.09 \pm 14.33$ & - & - & - & - \\
\hline $\begin{array}{l}\text { Toronto Western Spasmodic } \\
\text { Torticollis Rating Scale - severity } \\
\text { score }[\mathrm{pts}] \text {, mean } \pm \mathrm{SD}\end{array}$ & - & - & - & $15.55 \pm 6.41$ & - \\
\hline $\begin{array}{l}\text { Schwab-England Scale score } \\
\text { [pts], median }\end{array}$ & NA & 70 & 90 & NA & $<0.00001^{\ddagger}$ \\
\hline $\begin{array}{l}\text { Unified Huntington's Disease } \\
\text { Rating Scale - independence score } \\
{[\text { pts], mean } \pm \text { SD }}\end{array}$ & $76.30 \pm 11.40$ & $\mathrm{NA}$ & $\mathrm{NA}$ & $\mathrm{NA}$ & $\mathrm{NA}$ \\
\hline $\begin{array}{l}\text { Montgomery-Asberg Depression } \\
\text { Rating Scale [pts], median }\end{array}$ & 10 & 15 & 7 & 10.5 & $\begin{array}{l}0.0094^{* *} \\
\text { B vs. C }\end{array}$ \\
\hline $\begin{array}{l}\text { SD - standard deviation; } N A-\text { not assessed } \\
{ }^{*} \text { One-way analysis of variance with post-hoc Scheff } \\
{ }^{* * *} \text { Kruskal-Wallis test with post-hoc comparisons } \\
{ }^{* * * *} \chi^{2} \text { test } \\
\text { 'unpaired Student t-test } \\
\text { Mann-Whitney U-test }\end{array}$ & Iffe test & & & & \\
\hline
\end{tabular}


education. Due to the differences in the average age of onset (usually late in $\mathrm{PD}$, very variable in $\mathrm{HD}$ and cervical dystonia but most often earlier in these groups than in PD) and the onset of cognitive impairment (early in $\mathrm{HD}$ and rather late in PD), the groups could not be matched in terms of age. Only HD and cervical dystonia groups did not differ in terms of age. Huntington disease and advanced PD groups were matched in terms of general cognitive status according to the MMSE $[\mathrm{t}(46)=-0.52 ; p=0.60]$. Mood was significantly lower in advanced PD than in mild PD. All HD patients were treated with neuroleptics (sulpiride, $n=14$; tiapride, $n=6$; haloperidol, $n=4$; chlorprothixene, $n=1)$, and some of them took antidepressants $(n=19)$, muscle relaxants $(n=1)$ and benzodiazepine derivatives $(n=2)$. In the advanced PD group, the patients were treated with levodopa $(n=25)$, dopamine agonists $(n=18)$, amantadine $(n=11)$, antidepressants $(n=6)$, benzodiazepine derivatives $(n=3)$ and acetylcholinesterase inhibitors $(n=3)$. In the mild PD group, the patients were treated with levodopa $(n=20)$, dopamine agonists $(n=14)$, amantadine $(n=7)$, antidepressants $(n=4)$ and selegiline $(n=3)$. All patients with cervical dystonia received botulinum toxin injections, and one of them was additionally treated with muscle relaxants.

\section{Methods}

The questionnaires were filled in independently by the patients and the caregivers. The patients provided selfratings of memory prior to the neuropsychological assessment. PD patients were always tested in the 'on' phase. The study protocol was approved by the Medical University of Gdansk Bioethics Committee. The protocol was in accordance with the Helsinki Declaration.

\section{Neurological assessment}

Neurological assessment comprised the Motor Assessment and Independence Scale from the Unified Huntington's Disease Rating Scale (UHDRS) [29] in HD, part III from the Unified Parkinson's Disease Rating Scale (UPDRS) and the Schwab-England Scale [30] in PD and the Toronto Western Spasmodic Torticollis Rating Scale (TWSTRS) [31] in cervical dystonia.

\section{Neuropsychological assessment}

Neuropsychological assessment comprised general cognitive status testing (MMSE) [25] and verbal learning testing using modified 15-word list learning (Auditory Verbal Learning Test: AVLT) [32], devised by the authors (E.J.S. and D.W.) [33]. The following measures were analysed: the sum of words recalled in 5 learning trials (max. 75), corrected recognition score (true positive recognitions minus false positive recognitions (max. 15 ), number of words recalled over delay (max. 15), percentage of words recalled after delay (number of words recalled in the delayed recall trial divided by the average of the two highest scores from immediate recall) and corrected delayed recognition score (true positive recognitions minus false positive recognitions, max. 15). The patients' mood was assessed by means of the Montgomery-Asberg Depression Rating Scale (MADRS) [34], which is filled in by the examiner and not the patient, in order to avoid the influence of poor insight in $\mathrm{HD}$ on the depression scores.

\section{Assessment of self-awareness of symptoms}

The questionnaire memory assessment was performed by the patient and the caregivers using the adapted Self-Rating Scale of Memory Functions (SRSMF) [35]. The questionnaire comprises 18 items with ratings from 1 to 5 . The final score, which is the summation of item scores, ranges from 18 to 90 , where the higher score indicates more severe memory impairment. The Polish version of the scale was adapted for both the patient [36] and the caregiver [37]. After the testing, two measures of patient-caregiver agreement were computed apart from the raw scores. For each patient-caregiver pair, an average absolute patient-caregiver difference score (AADS) was computed on the basis of all items, in order to assess the disagreement, regardless of its direction: underestimation or overestimation of impairment by the patients [21]. Subsequently, on the basis of items in which the patients assessed their memory function as better than the caregiver, the underestimation score (US) was computed [37].

\section{Statistical analysis}

Normality of distribution was tested with Shapiro-Wilk W-test and homogeneity of variance was assessed with Levene's test. The intergroup differences for the four groups were tested using one-way analysis of variance with posthoc Scheffe test or Kruskal-Wallis H-test with post-hoc comparisons [38]. Differences between two groups were analysed using the Mann-Whitney $U$-test, unpaired Student $t$-test or $\chi^{2}$ test. Correlation analyses were performed 
using Spearman rank correlation coefficients. A conventional alpha of 0.05 was used in all the analyses.

\section{Results}

In terms of objective memory testing (AVLT), both the sum of words recalled in trials I-V and the sum of words recalled over the delay were significantly lower in $\mathrm{HD}$ than in mild PD and cervical dystonia. The delayed recognition score was lower in HD than in the other clinical groups (Table 2).

The analysis of the intergroup differences in SRSMF revealed that according to the caregivers the memory impairment was greater in HD than in cervical dystonia, which is in accordance with the AVLT results. However, when patients' ratings are considered, the only significant difference was between advanced PD and mild PD. Absolute average difference scores and underestimation scores were significantly higher in HD than in cervical dystonia.

Subsequently, the correlation analysis of patients' and caregivers' ratings with the selected measures from AVLT was performed. In the HD group, there were no associations between patients' or caregivers' ratings and AVLT scores. In the advanced PD group, sum of words recalled in trials I-V correlated negatively both with the patients' ratings (rho $=-0.54 ; p<0.05$ ) and the caregivers' ratings (rho $=-0.56 ; p<0.01$ ). In the mild PD group, the percentage of words recalled after 10 minutes cor-

Table 2. The results of neuropsychological assessment and the questionnaire assessment of memory impairment severity in Huntington disease (HD), advanced Parkinson disease (PD), mild PD and cervical dystonia

\begin{tabular}{|c|c|c|c|c|c|}
\hline & $\begin{array}{l}\text { Patients with } \mathrm{HD} \\
\qquad \begin{array}{c}N=23 \\
{[\mathrm{~A}]}\end{array}\end{array}$ & $\begin{array}{c}\text { Patients with } \\
\text { advanced PD } \\
N=25 \\
\text { [B] }\end{array}$ & $\begin{array}{l}\text { Patients with mild PD } \\
\qquad N=21 \\
{[\mathrm{C}]}\end{array}$ & $\begin{array}{l}\text { Patients with } \\
\text { cervical dystonia } \\
N=20 \\
\text { [D] }\end{array}$ & $\begin{array}{l}P \text {-value for } \\
\text { differences } \\
\text { between } \\
\text { groups }\end{array}$ \\
\hline $\begin{array}{l}\text { Mini-Mental State Examination } \\
\text { score }[\mathrm{pts}] \text {, median }\end{array}$ & 26 & 27 & 28 & 28.5 & $0.02 *$ \\
\hline $\begin{array}{l}\text { AVLT }- \text { I-V trials }[\mathrm{pts}] \\
\text { mean } \pm \mathrm{SD}\end{array}$ & $29.5 \pm 8.33$ & $38.2 \pm 11.78$ & $41.33 \pm 12.65$ & $44.60 \pm 11.02$ & $\begin{array}{c}0.002 * * \\
\text { A vs. C, A vs. D }\end{array}$ \\
\hline $\begin{array}{l}\text { AVLT - corrected recognition } \\
{[\mathrm{pts}], \text { median }}\end{array}$ & 9 & 14 & 13 & 13 & $\begin{array}{c}0.0002 * \\
\text { A vs. B, A vs. C, } \\
\text { A vs. D }\end{array}$ \\
\hline $\begin{array}{l}\text { AVLT - delayed recall }[\mathrm{pts}] \\
\text { mean } \pm \mathrm{SD}\end{array}$ & $5.52 \pm 2.69$ & $7.68 \pm 3.24$ & $8.67 \pm 2.99$ & $9.90 \pm 3.68$ & $\begin{array}{l}0.002 * * \\
\text { A vs. C, A vs. D }\end{array}$ \\
\hline $\begin{array}{l}\text { AVLT - delayed recall }[\%] \\
\text { mean } \pm \mathrm{SD}\end{array}$ & $71.33 \pm 21.70$ & $79.39 \pm 18.38$ & $86.39 \pm 17.39$ & $87.21 \pm 19.83$ & $0.03 * *$ \\
\hline $\begin{array}{l}\text { AVLT - delayed recognition }[\mathrm{pts}] \\
\text { median }\end{array}$ & 8 & 12 & 11 & 12 & $\begin{array}{c}0.0019^{*} \\
\text { A vs. B, A vs. C, } \\
\text { A vs. D }\end{array}$ \\
\hline $\begin{array}{l}\text { SRSMF - patient's ratings [pts], } \\
\text { median }\end{array}$ & 68 & 68 & 60 & 62.5 & $\begin{array}{c}0.03^{*} \\
\text { B vs. C }\end{array}$ \\
\hline $\begin{array}{l}\text { SRSMF - caregiver's ratings } \\
{[\mathrm{pts}], \text { median }}\end{array}$ & 69 & 64 & 61 & 60 & $\begin{array}{l}0.009^{*} \\
\text { A vs. D }\end{array}$ \\
\hline $\begin{array}{l}\text { SRSMF - patient-caregiver } \\
\text { difference: raw score, median }\end{array}$ & -2 & 5 & 0 & 2 & 0.047 * \\
\hline $\begin{array}{l}\text { SRSMF - average of absolute } \\
\text { differences between patients and } \\
\text { caregivers, median }\end{array}$ & 0.67 & 0.56 & 0.39 & 0.39 & $\begin{array}{l}0.04^{*} \\
\text { A vs. D }\end{array}$ \\
\hline $\begin{array}{l}\text { SRSMF - underestimation score, } \\
\text { median }\end{array}$ & 6 & 3 & 3 & 2 & $\begin{array}{l}0.014^{*} \\
\text { A vs. D }\end{array}$ \\
\hline
\end{tabular}

SD - standard deviation; AVLT - Auditory Verbal Learning Test; SRSMF - Self-Rating Scale of Memory Function

*Kruskal-Wallis test with post-hoc comparison

**one-way analysis of variance with post-hoc Scheffe test 
related negatively with the caregivers' ratings ( $r$ o $=-0.57$; $p<0.01)$. In the cervical dystonia group, the patients' ratings correlated negatively with the sum of words recalled in trials I-V (rho $=-0.63 ; p<0.01)$, corrected immediate recognition score ( $\mathrm{rho}=-0.45 ; p<0.05$ ) and sum of words recalled after the delay (rho $=-0.48$; $p<0.05)$. In the same group, the caregiver's ratings correlated negatively with the sum of words recalled in trials I-V (rho $=-0.72 ; p<0.01$ ), corrected immediate recognition score (rho $=-0.62 ; p<0.01)$ and the sum of words recalled after delay (rho $=-0.54 ; p<0.05$ ).

Subsequently, the correlation analysis of AADS and US with MMSE, MADRS, disease duration in years, UHDRS motor score and UHDRS independence scale was performed for the HD group. AADS correlated with the UHDRS motor score ( $r h o=0.45 ; p<0.05$ ) and UHDRS independence scale score ( $\mathrm{rho}=-0.49$; $p<0.05$ ). It means that greater symptom severity in $\mathrm{HD}$ was associated with more inadequate self-ratings of memory. Disease duration was associated with AADS $($ rho $=0.53 ; p<0.05)$. There were no associations between self-awareness measures and MMSE or MADRS.

\section{Discussion}

Data from the literature suggest that self-awareness of memory impairment may be affected in HD, as in the case of other domains. A few questions addressing memory were included in some of the previous questionnaire studies $[20,21,23]$, but they did not allow one to evaluate the self-awareness of memory impairment in HD, as memory was not assessed as a separate component in those studies. In a study by Ho et al. [23], the Dysexecutive Questionnaire was used, in which some of the questions concern the executive component of memory. However, the factor analysis did enable the disentangling of the memory component. In none of the previous studies was the insight into memory impairment in $\mathrm{HD}$ specifically analysed. Therefore, our study is the first one to address the self-awareness of memory impairment in HD.

In our study, verbal learning and delayed recall were similarly affected in $\mathrm{HD}$ and advanced PD, which is in accordance with the literature on the relatively similar profile of episodic memory impairment in HD and PD [16]. However, slightly more severe episodic memory impairment in HD than in other clinical groups, as shown by poorer recognition performance, cannot be attributed to depressed mood, as mood differentiated between the two PD groups, but not between $\mathrm{HD}$ and other clinical groups.
No associations were detected in HD between the objective memory testing results and the self-ratings of memory. However, underestimation of memory impairment was noted on the basis of patient-caregiver comparison, which is in accordance with data on the deficient selfawareness in HD in other motor and cognitive domains [17-23].

Different causes of impaired insight in HD are hypothesized: (1) cognitive: global cognitive impairment, memory impairment, deficient monitoring-cognitive control, (2) emotional: avoidance coping, mood disturbance, (3) disease-related: symptom severity and sensory deficits (in case of involuntary movements perception) [19]. In the present study, impaired insight was associated with greater disease severity, which is in accordance with the progressive nature of the disorder [39].

Deficient self-awareness in HD had been frequently associated with prefrontal pathology, but it was demonstrated that orbitofrontal dysfunction is also present in mild PD without dementia $[40,41]$. What is more, neurodegeneration in HD does not affect frontal lobes in a selective manner, as there is a growing body of evidence on extra-fronto-striatal dysfunction even early in the course of $\mathrm{HD}$, especially in the posterior brain regions and within the corpus callosum [42-45]. Because of the lack of neuroimaging data in our study, it does not add to the knowledge about brain correlates of deficient self-awareness in HD.

Notably, in HD not only the patients' ratings but also the caregivers' ratings did not correspond with the objective memory assessment results. The HD caregivers' did assess the patients' memory capacity as inferior to that of cervical dystonia patients. However, in contrast to all the other clinical groups, in HD there was no association between the objective assessment results and caregivers' ratings. This may imply that not only $\mathrm{HD}$ patients, but also the caregivers may be biased in the subjective memory ratings. Inadequate caregiver ratings may be due to defence mechanisms or the poor awareness of the specificity of memory impairment in HD. On the one hand, memory impairment can be attributed to age (the average in the HD group was $49.83 \pm 11.12$ years). On the other hand, because of predominant motor disability or psychiatric symptoms in the patients, the caregivers may need to believe in the preserved cognitive functions of their patients. Moreover, in Polish society memory impairment is usually associated with Alzheimer disease, while in $\mathrm{HD}$ the memory deficits are not only milder, but also have a different specificity: poor spontaneous recall with better recognition and cued recall $[6,12,13,16]$. 
It may also contribute to the difficulties with interpretation of memory problems by the caregivers.

Our study has several shortcomings. Firstly, the groups were relatively small, albeit not smaller than in two other studies addressing self-awareness in HD with clinical comparison groups: with 9 HD patients [18] or $23 \mathrm{HD}$ patients [19]. Secondly, neuropsychological assessment addressed only memory and it was not possible to study the effect of other cognitive dysfunctions on the self-awareness of deficits. What is more, only verbal learning was assessed, while the other aspects of memory (e.g. verbal memory of structured material, visual memory) were not tested. AVLT was chosen because it was used in previous studies with SRSMF $[37,46]$ and due to the sensitivity of verbal learning measures in subcortical dementias. Lastly, as HD patients were treated with different neuroleptics and other drugs, the effect of medication on the self-awareness of symptoms could not be analysed due to the heterogeneity of treatment regimens.

Due to the lack of medication that could address memory impairment in $\mathrm{HD}$, the recognition of those deficits does not influence the pharmacotherapy decisions. However, it is crucial for the caregiver's education and counselling [47]. For instance, the diagnosis of significant memory impairment in HD justifies the supervision of medication taking by the caregiver. Therefore, similar studies are not only of cognitive but also of practical importance.

\section{Conclusions}

Insight into memory impairment is significantly compromised in HD. Poor self-awareness of memory impairment in HD is associated with longer disease duration and greater disease severity.

\section{Acknowledgements}

The paper was written thanks to the financial support provided by the Foundation for Polish Science (FNP). While preparing the paper, EJS received a START Scholarship from FNP. The authors wish to thank Prof. Janusz Limon from the Department of Biology and Genetics, Medical University of Gdansk, for his help in genetic counselling and HD patients' recruitment.

\section{Disclosure}

Authors report no conflict of interest.

\section{References}

1. Kremer B. Clinical neurology of Huntington's disease. In: Bates G., Harper P.S., Jones L. [eds.]. Huntington's disease. Oxford University Press, New York 2002, pp. 28-61.

2. Craufurd D., Snowden J. Neuropsychological and neuropsychiatric aspects of Huntington'a disease. In: Bates G., Harper P.S., Jones L. [eds.]. Huntington's disease. Oxford University Press, New York 2002, pp. 62-94.

3. Stout J.C., Paulsen J.S., Queller S., et al. Neurocognitive signs in prodromal Huntington disease. Neuropsychology 2011; 25: 1-14.

4. Montoya A., Pelletier M., Menear M., et al. Episodic memory impairment in Huntington's disease: a meta-analysis. Neuropsychologia 2006; 44: 1984-1994.

5. Sitek E.J., Sołtan W., Sławek J. Rola neuropsychologa w diagnostyce i leczeniu choroby Huntingtona. Post Psychiatr Neurol 2011; 20: 23-31.

6. Rohrer D., Salmon D.P., Wixted J.T., et al. The disparate effects of Alzheimer's disease and Huntington's disease on semantic memory. Neuropsychology 1999; 13: 381-388.

7. Knowlton B.J., Swerdlow N.R., Swenson M., et al. Dissociations within nondeclarative memory in Huntington's disease. Neuropsychology 1996; 10: 538-548.

8. Gabrieli J.D.E., Willingham D.B., Stebbins G.T., et al. Intact mirror-tracing and impaired rotary-pursuit skill learning in patients with Huntington's disease: evidence for dissociable memory systems in skill learning. Neuropsychology 1997; 11: 272-281.

9. Maki P.M., Bylsma F.W., Brandt J. Conceptual and perceptual implicit memory in Huntington's disease. Neuropsychology 2000; 14: 331-340.

10. Solomon A.C., Stout J.C., Johnson S.A. Verbal episodic memory declines prior to diagnosis in Huntington's disease. Neuropsychologia 2007; 45: 1767-1776.

11. Pirogovsky E., Goldstein J., Peavy G., et al. Temporal order memory deficits prior to clinical diagnosis in Huntington's disease. J Int Neuropsychol Soc 2009; 15: 662-670.

12. Sadek J.R., Johnson S.A., White D.A., et al. Retrograde amnesia in dementia: comparison of HIV-associated dementia, Alzheimer's disease, and Huntington's disease. Neuropsychology 2004; 18: 692-699.

13. Brandt J., Shpritz B., Munro C.A., et al. Differential impairment of spatial location memory in Huntington's disease. J Neurol Neurosurg Psychiatry 2005; 76: 1516-1519.

14. Zakzanis K.K. The subcortical dementia of Huntington's disease. J Clin Exp Neuropsychol 1998; 20: 565-578.

15. Fine E.M., Delis D.C., Wetter S.R., et al. Identifying the "source" of recognition memory deficits in patients with Huntington's disease or Alzheimer's disease: Evidence from the CVLT-II. J Clin Exp Neuropsychol 2008; 30: 463-470.

16. Aretouli E., Brandt J. Episodic memory in dementia: characteristics of new learning that differentiate Alzheimer's, Huntington's, and Parkinson's diseases. Arch Clin Neuropsychol 2010; 25: 296-309.

17. Snowden J.S., Craufurd D., Griffiths H.L., et al. Awareness of involuntary movements in Huntington disease. Arch Neurol 1998; 55: 801-805. 
18. Vitale C., Pellecchia M.T., Grossi D., et al. Unawareness of dyskinesias in Parkinson's and Huntington's diseases. Neurol Sci 2001; 22: 105-106.

19. Sitek E.J., Sołtan W., Wieczorek D., et al. Self-awareness of motor dysfunction in patients with Huntington's disease in comparison to Parkinson's disease and cervical dystonia. J Int Neuropsychol Soc 2011; 17: 788-795.

20. Deckel A.W., Morrison D. Evidence of a neurologically based "denial of illness" in patients with Huntington's disease. Arch Clin Neuropsychol 1996; 11: 295-302.

21. Hoth K.F., Paulsen J.S., Moser D.J., et al. Patients with Huntington's disease have impaired awareness of cognitive, emotional and functional abilities. J Clin Exp Neuropsychol 2007; 29: 365-376.

22. Chatterjee A., Anderson K.E., Moskowitz C.B., et al. A comparison of self-report and caregiver assessment of depression, apathy, and irritability in Huntington's disease. J Neuropsychiatry Clin Neurosci 2005; 17: 378-383.

23. Ho A., Robbins A.O.G., Barker R.A. Huntington's disease patients have selective problems with insight. Mov Disord 2006; 21: 385-389.

24. Duff K., Paulsen J.S., Beglinger L.J., et al. "Frontal” behaviors before the diagnosis of Huntington's disease and their relationship to markers of disease progression: evidence of early lack of awareness. J Neuropsychiatry Clin Neurosci 2010; 22: 196-207.

25. Folstein M.F., Folstein S.E., McHugh P.R. Mini-mental state. J Psychiatr Res 1975; 12: 189-198.

26. Clare L., Markova I., Verhey F., et al. Awareness in dementia: A review of assessment methods and measures. Aging Ment Health 2005; 9: 394-413.

27. Litvan I., Bhatia K.P., Burn D.J., et al. Movement Disorders Society Scientific Issues Committee Report: SIC Task Force appraisal of clinical diagnostic criteria for parkinsonian disorders. Mov Disord 2003; 18: 467-486.

28. Albanese A., Barnes M.P., Bhatia K.P., et al. A systematic review on the diagnosis and treatment of primary (idiopathic) dystonia and dystonia plus syndromes: report of an EFNS/MDS-ES Task Force. Eur J Neurol 2006; 13: 433-444.

29. Huntington Study Group. Unified Huntington's Disease Rating Scale: reliability and consistency. Mov Disord 1996; 11: 136-142.

30. Paulson H.L., Stern M.B. Clinical manifestations of Parkinson's disease. In: Watts R.L., Koller W.C. [eds.]. Movement disorders - neurologic principles and practice. Mc Graro-Hill Companies, New York 1997, pp. 183-199.

31. Comella C.L., Stebbins G.T., Goetz C.G., et al. Teaching tape for the motor section of the Toronto Western Spasmodic Torticollis Scale. Mov Disord 1997; 12: 570-575.

32. Choynowski M., Kostro B. Podręcznik do testu 15 słów A. Rey’a. Wyd. PWN, Warszawa 1980.

33. Sitek E.J. Neuropsychologiczna ocena samoświadomości objawów w chorobach Huntingtona, Parkinsona oraz w dystonii szyjnej. Unpublished doctoral thesis. Gdanski Unirwersytet Medyczny, Gdańsk 2010

34. Montgomery S.A., Asberg M. A new depression scale designed to be sensitive to change. BrJ Psychiatry 1979; 134: 382-389.
35. Squire L.R., Zouzounis J.A. Self-ratings of memory dysfunction: different findings in depression and amnesia. J Clin Exper Neuropsychol 1988; 10: 727-738.

36. Wieczorek D., Jodzio K., Radziwiłłowicz W. Skargi subiektywne a wyniki testów pamięci w depresji i rozlanych uszkodzeniach mózgu. Psychiatr Pol 1996; 30: 641-652.

37. Sitek E., Soltan W., Wieczorek D., et al. Self-awareness of memory function in Parkinson's disease in relation to mood and symptom severity. Aging Ment Health 2011; 15: 150-156.

38. Siegel S., Castellan N.J. Nonparametric statistics for the behavioral sciences. McGraw-Hill, New York 1988.

39. Tranel D., Paulsen J.S., Hoth K.F. Anosognosia in Huntington's disease. In: Prigatano G.P. [ed.]. The study of anosognosia. Oxford University Press, New York 2010, pp. 159-169.

40. Lyoo C.H., Ryu Y.H., Lee M.S. Topographical distribution of cerebral cortical thinning in patients with mild Parkinson's disease without dementia. Mov Disord 2010; 25: 496-499.

41. Tinaz S., Courtney M.G., Stern C.E. Focal cortical and subcortical atrophy in early Parkinson's disease. Mov Disord 2011; 26: 436-441.

42. Douaud G., Behrens T.E., Poupon C., et al. In vivo evidence for the selective subcortical degeneration in Huntington's disease. Neuroimage 2009; 46: 958-966.

43. Halliday G.M., McRitchie D.A., Macdonald V., et al. Regional specificity of brain atrophy in Huntington's disease. Exp Neurol 1998; 154: 663-672.

44. Rosas H.D., Lee S.Y., Bender A.C., et al. Altered white matter microstructure in the corpus callosum in Huntington's disease: implications for cortical "disconnection". Neuroimage 2010; 49: 2995-3004.

45. Della Nave R., Ginestroni A., Tessa C., et al. Regional distribution and clinical correlates of white matter structural damage in Huntington disease: a tract-based spatial statistics study. AJNR Am J Neuroradiol 2010; 31: 1675-1681.

46. Ivory S.J., Knight R.G., Longmore B.E., et al. Verbal memory in non-demented patients with idiopathic Parkinson's disease. Neuropsychologia 1999; 37: 817-828.

47. Sitek E.J., Sławek J., Wieczorek D. Samoświadomość objawów w chorobach Huntingtona i Parkinsona. Psychiatr Pol 2008; 42: 393-403. 